\title{
Bioinformation
}

\section{Current status of immunology research in India}

\author{
Avadhesha Surolia and Ravi Dhar* \\ National Institute of Immunology, Aruna Asaf Ali Marg, New Delhi-110 067, India; \\ Ravi Dhar* - Email: ravi@nii.res.in; * Corresponding author \\ received July 06, 2007; revised July 09, 2007; accepted July 10, 2007; published online July 10, 2007
}

\begin{abstract}
:
Rudimentary studies on aspects of biochemistry in India date back to 1927. But, in the field of Immunology, such studies were started by scholars only during early 1970s at the All India Institute of Medical Sciences, New Delhi, India. Science and Technology was not an immediate priority until 1961 due to domestic and political conditions in the country. We were then 11 years old since independence and our focus was on economic and social developments. Gradually, improvements were made in the field and now we have 15 to 20 major groups (small in size) of immunologists in the country, who have made significant contribution in the field during the last 8 to 10 years. Hence, we anticipate improvements in manpower and infrastructure in the near future.
\end{abstract}

Keywords: infrastructure; manpower; immunology research; India

\section{Background:}

Literature reveals references to immunology in 1932 followed by a serious monograph on "The Production of Antibodies" in 1949 by Sir F.M. Burnet and Dr. Frank Fenner and the theory of clonal selection theory of acquired immunity published in 1959 [1, 2] which laid foundation for a new subject called Immunology. At that point of time, India was a 9 year old democracy trying to stabilize itself with its limited resources. Obviously research in $\mathrm{S}$ and $\mathrm{T}$ was not the immediate priority.

It is important to give a brief background of how life sciences developed in India after independence. The Council of Scientific and Industrial Research (CSIR) was given the prime responsibility to develop a research base for India by the then Prime Minister of India Pt. Jawaharlal Nehru. University, college and science education was coordinated by Ministry of Education from 1961 onwards. Subsequently a Department of Science and Technology was created in 1971; scientific activity was primarily conducted under this ministry. The intellectual and human capital of the country was further streamlined by creation of a separate Ministry of Human Resource Development in 1985 followed by creating a separate Department for Biotechnology in 1986.

\section{Birth of Immunology in India}

Immunology in India just like that in other nations, started as an offshoot of Biochemistry. Research in the area of Biochemistry in India can be traced to 1930 s with publications related to "isolation of growth promoting factors in Bios" [3] to "anticoagulant activity of fluorides, citrates and oxalates" to confirmation of classic work on "formation of Penicillin by $P$. notatum from lysine and $\beta$ hydroxy valine". [4] This was followed by a big gap till thirty years later (in late 1960s), a group of dedicated biochemists like Profs. P. Sharma, G.P. Talwar, B.K. Bachhawat, M.C. Vaidya, D.P. Burma, C. Gopalan, A. Sreenivasan, L.K. Ramachandaran and K. Radhakrishnan plunged into active research with limited means. In this journey, impetus to immunology in India was given by a group of scholars from the Department of Biochemistry at the Aii India Institute of Medical Sciences, New Delhi, India (AIIMS) in 1970s (example, Lymphocytes bearing immunoglobulin determinants in normal human lymph nodes and in patients with lepromatous leprosy or Status of humoral immune responses in leprosy or mechanism of regulation of immune response $[5,6,7]$ or an evaluation of the immune state in leprosy. [8]) The AIIMS group was the first in India to harvest hybridomas (example, Development of hybridomas secreting anti-human chorionic gonadotropin antibodies. [9] However, references to preparation of vaccine against Vaccinia virus can be traced to 1952 [10] and subsequently to works of D'Monte and Talwar (1967). [11] A brief review on Immunology in India and its weaknesses can be traced to Mitchison in 1986. [12]

\section{Recent Achievements}

To gain visibility in the area of immunology, India got a chance to host the $10^{\text {th }}$ International Immunology Conference in New Delhi in 1998 (pib.nic.in/archieve/lreleng/lyr98/11098/r261098.html). The international community got exposed to strengths and weaknesses of the Indian immunology scenario. Ever since then, a gradual rise in clinical collaborations started, which continue to rise till date. In the meantime, over the period of last 20 to 25 years, scholars from the All India Institute of Medical Sciences, Department of Biotechnology and 


\section{Bioinformation}

\section{www.bioinformation.net}

\section{Views \& Challenges}

Indian Council of Medical Research worked hard to put Indian immunology on a serious path. However, while as the quality of work has considerably improved, the output is still low. One of the reasons for this could be that, most of the biological research in India is driven more by the "chemical perspective" [13] but this may not be the only reason. Other reason is the lack of availability of manpower in the area. It would be worthwhile if more members of medical fraternity get drawn into the research area in addition to their basic interest in patient management. Surprisingly, at the moment, we have 15 to 20 major scholars working in so many aspects of immunology (Tables 1 and 2 see supplementary material) while several others use immunology as a tool which has not been discussed in this paper. The net outcome is a few great peer reviewed publications that could give great competition to big laboratories around the world e.g., 10 out of 60 molecular or protein structures of genomes of infectious diseases have been solved in India. This is a great feat indeed. One also needs to keep in mind that research infra-structure plays a great role in achieving goals.

The world class infrastructure at several organizations including at NII need to be further improved and best use made of existing structures. In the area of immunology of infectious diseases, P3 laboratories are being built or have been planned to be built at 10 to 12 places around the country so as to handle deadly organisms like Mycobacterium, Influenza virus, and HIV-AIDS. In order to run the show while as the number of key players remains more or less static, more key players need to jump into fray otherwise this could slow down the progress and hamper creation of a great bank in immunology research. A significant number of trained manpower leave India for their post doctoral studies, but very few of them return back in the area of immunology, unlike in other fields. The third component which results in lesser output is the funding position in the area of immunology. This has a bearing on the total spending on education and scientific research in India which in 2005 was 3.8 percent of GDP. This is too low to push front line research. When compared to USA, the finance budget of NIH for the FY 2008 is around US \$ 60,000 million. This matches the total budget of India for various activities for full one year under several departments including that of health and medical research. In spite of these impediments, collaborators proposals from abroad are growing and till we fine tune ourselves with several types of resources, it is advisable to prudently continue with multi-pronged strategy to give a push to the subject. The status of clinical immunology by the Indian scientist is equally worrisome. Indian Council of Medical Research has considerably geared use of clinical immunology around the country. ELISA tests and PCR are increasingly used for detection of several diseases including surveillance of blood banks for HIV-1 and -
2 as well as Hepatitis. An immuno-modulatory vaccine for leprosy is in market as a part of multi-drug therapy for the disease. At a number of places immunogenic studies and toxicological studies of several vaccines on small animals has become a routine exercise. Other vaccine developments are in pipe line. Various programs and activities which have been going on in the area of immunology and related are of biotechnology can be had from some of the following websites: http://dbtindia.nic.in/; http://www.nii.res.in/; http://www.aiims.edu/; http://www.icmr.nic.in/.

\section{Conclusion:}

We are witnessing a change in the field of immunological research in India but at a slower pace due to paucity of scholars in the area. One very important filed that needs to grow at faster pace is in the area of disease resistance and susceptibility. As mentioned earlier, there is a rapid need to improve infrastructure and add manpower in laboratories close to disease endemic areas so that local diseases and their remedies are better addressed.

\section{Acknowledgements:}

Drs. Ayub Qadri, Rahul Pal and Satish Gupta for giving some historical details about growth of immunology during their student days in Prof. G.P. Talwar's and other laboratories at the All India Institute of Medical Sciences, New Delhi, India.

\section{References:}

[01] F. M. Burnet and F. Fenner, The Quarterly Review of Biology, 26:220 (1951)

[02] http://www.pubmedcentral.nih.gov/articlerender.fcgi?artid $=1522512$

[03] B. T. Narayanan, Biochem J., 24:6 (1930) [PMID: 16744353]

[04] U. D. Deshmukh, et al., J Postgrad Med., 44:222 (2001)

[05] R. C. Verma, et al., Int J Lepr Other Mycobact Dis., 39:20 (1971) [PMID: 4106081]

[06] P. Jha, et al., Int J Lepr Other Mycobact Dis., 39:14 (1971) [PMID: 5106540]

[07] R. Krishnaraj and G. P. Talwar, Biochem J., 128:57 (1972) [PMID: 4343668]

[08] N. K. Mehra et al., Lepr India, 48:231 (1976) [PMID: 15165]

[09] S. K. Gupta and G. P. Talwar, Indian J Exp Biol., 18:1361 (1980) [PMID: 7228117]

[10] R. S. Rao, Indian J Med Res., 40:341 (1952) [PMID: 3034295]

[11] B. D'Monte and G. P. Talwar, J Neurochem., 14:743 (1967) [PMID: 4961470]

[12] A. Mitchison, Nature, 323:752 (1986) [PMID: 3774003]

[13] http://www.ias.ac.in/currsci/mar102001/599.pdf

Edited by $P$. Kangueane

Citation: Surolia \& Dhar, Bioinformation 2(1): 34-38 (2007)

License statement: This is an open-access article, which permits unrestricted use, distribution, and reproduction in any medium, for non-commercial purposes, provided the original author and source are credited. 


\section{Bioinformation}

www.bioinformation.net

open access

\section{Views \& Challenges}

\begin{tabular}{|c|c|c|c|c|c|}
\hline S. No & Broad areas of research & $\begin{array}{l}\text { Investigator/ organization/ } \\
\text { Year }\end{array}$ & Disease worked & I.F & $\begin{array}{l}\text { Number of } \\
\text { Publications }\end{array}$ \\
\hline \multirow[t]{2}{*}{1.} & $\begin{array}{l}\text { \#Study of components \& mechanisms involved in innate } \\
\text { immune response. Understand mechanisms by which the } \\
\text { innate response modulates the adaptive immune response }\end{array}$ & Ayub Qadri/ NII/ 1982 & -Mechanism for immunity against bacteria & $>3$ to 20 & 14 \\
\hline & & $\begin{array}{l}\text { Jyoti Basu/BI/1990 } \\
\text { Vineeta Bal/NII/2006 }\end{array}$ & $\begin{array}{l}\text {-Innate immunity to TB } \\
\text {-TLRs in filarial }\end{array}$ & $<7$ & $14 \$$ \\
\hline \multirow[t]{2}{*}{2.} & $\begin{array}{l}\text { \#Events leading to activation, proliferation, death and } \\
\text { homeostasis in lymphocytes (T cells, B cells \& NK cells) }\end{array}$ & $\begin{array}{l}\text { Satyajit Rath/NII /1995 } \\
\text { Vineeta Bal/NII/ } 1995 \\
\text { Anna George/NII/ } 1998 \\
\text { Agrewala/IMTECH/1998 }\end{array}$ & $\begin{array}{l}\text {-Processing proteins antigens for presentation to T-cells } \\
\text {-Mucosal immunology } \\
\text {-Inflammatory responses \& immuno-modulation }\end{array}$ & $\begin{array}{l}>5 \\
>5 \\
<5 \\
>4 \text { to } 10\end{array}$ & $\begin{array}{l}60 \\
50 \\
30 \\
27\end{array}$ \\
\hline & & $\begin{array}{l}\text { Apurva Sarin/NCBS/1994 } \\
\text { S.Chiplunkar/ACTREC/1993 }\end{array}$ & $\begin{array}{l}\text {-Immune activation } \\
\text {-Mechanism of Signaling in T-cells }\end{array}$ & $\begin{array}{l}<6 \\
>3 \text { to } 5\end{array}$ & $\begin{array}{l}25 \\
39\end{array}$ \\
\hline \multirow[t]{4}{*}{3.} & $\begin{array}{l}\text { \#Mediators and mechanisms involved in the interaction of } \\
\text { lymphoid and non-lymphoid cells under normal, pathogenic } \\
\text { and aberrant conditions }\end{array}$ & $\begin{array}{l}\text { Satyaji Rath/NII/1995 } \\
\text { GC Mishra/NCCS/1994 }\end{array}$ & $\begin{array}{l}\text {-Mechanism of antigen presentation } \\
\text {-Mechanisms of } \mathrm{T} \text {-cell differentiation }\end{array}$ & $\begin{array}{l}>3 \text { to } 9 \\
>3 \text { to } 6\end{array}$ & $\begin{array}{l}60 \\
24\end{array}$ \\
\hline & & Sahid Jameel/ICGEB/1992 & -Pathogenesis of Hepatitis virus & $<3$ & 11 \\
\hline & & Sita Naik/SGPGI/1986 & -Cellular immunology \& immunomoodulation & $<3$ & 30 \\
\hline & & B. Saha/ NCCS/ 1995 & -Humoral Immnity to Leishmania; \& tumour biology & $<5$ & 49 \\
\hline \multirow[t]{4}{*}{4.} & $\begin{array}{l}\text { \#Characterization of cells and mechanisms involved } \\
\text { in immunological memory }\end{array}$ & Satyajit Rath/ NII/1984 & -Immuno-modulation & $>4$ & 60 \\
\hline & & Vineeta Bal/NII/1983 & -Immunological memory & $>4$ & 50 \\
\hline & & Kanury Rao/ ICGEB/ & $\begin{array}{l}\text {-Genes related to adaptive immunity \& activation of } \\
\text { humoral responses }\end{array}$ & $>4$ to 20 & 60 \\
\hline & & Dinakar Salunke/NII/ 1998 & -Structural biology of immune complexes & $>10$ & 15 \\
\hline
\end{tabular}




\section{Bioinformation}

www.bioinformation.net

open access

\section{Views \& Challenges}

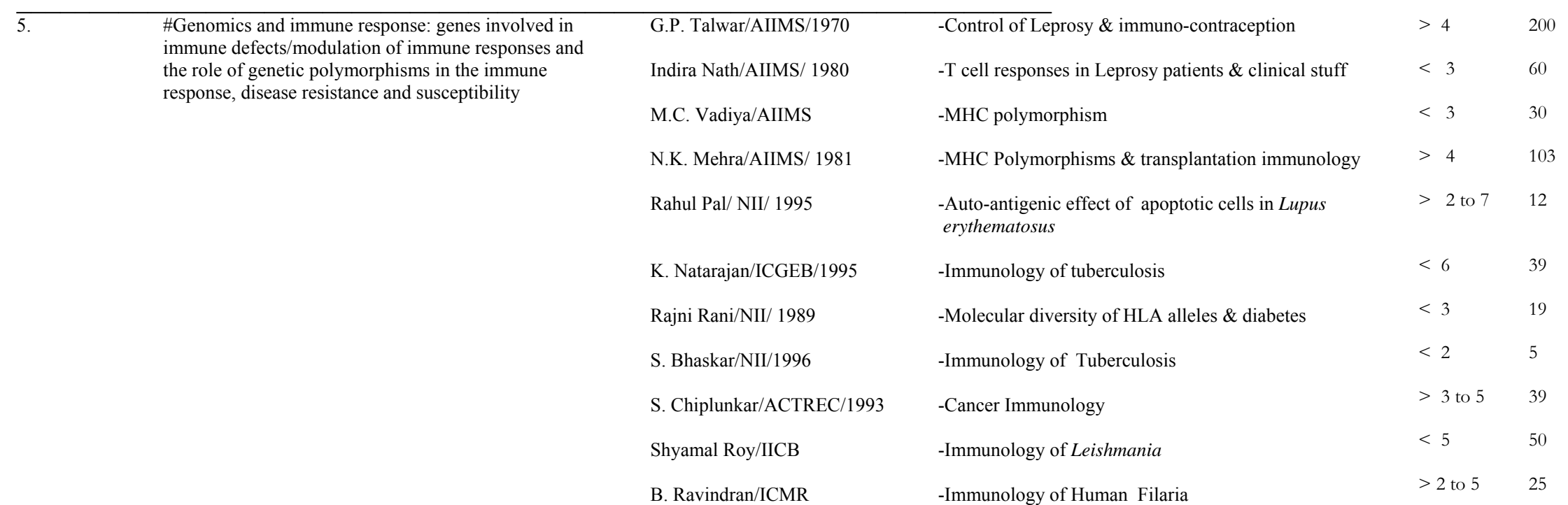

Table 1: Basic Immunology. Note: the no. of publications shown here relate to the field of immunology; a low impact factor (I.F.) does not necessarily mean low quality of research. Many investigators publish their findings only in very specialized journals and thus can not be compared to other publications of general nature where I.F. is skewed to a higher level. (Legends for abbreviations: \#=classification as per Nandi and Sarin (2001) [14]; \$= work started recently; NII=National Institute of Immunology, New Delhi; BI=Bose Institute, Kolkata;

IMTEC=Institute of Microbial Technology, Chandigarh; NCBS=National Center for Biological Sciences, Pune; ACTREC=Advanced Center for Treatment, Research and Education in Cancer, Bombay; NCCS=National Center for Cell Science, Pune; ICGEB=International Center for Genetic Engineering \& Biotechnology, New Delhi; SGPGI=Sanjay Gandhi Post Graduate Institute of Medical Sciences; IICB=Indian Institute of Chemical Biology, Kolkota; ICMR=Indian Council of Medical Research, Orissa

\begin{tabular}{|c|c|c|c|}
\hline S. No. & Broad areas of research & Investigator/ Organization/ Year & Progress \\
\hline \multirow[t]{6}{*}{1.} & Vaccine development & G.P. Talwar/ NII/ 1990s & -Anti-hGC vaccine ${ }^{1}$ \\
\hline & & Sudhanshu Vrati/ NII/2003 & -JEV vaccine ${ }^{2}$ \\
\hline & & Sita Naik/SGPGI & -Leishmania \\
\hline & & Chetan Chitnis \& V.Chauhan/ICGEB/2003 & -Malaria ${ }^{3}$ \\
\hline & & D.N. Rao/ AIIMS/1998 & -Novel adjuvants/delivery systems \\
\hline & & M.K. Bhan/AIIMS/2005 & -Rotavirus ${ }^{4}$ \\
\hline \multirow[t]{3}{*}{2.} & Therapeutics & G.P.Talwar/ NII/1990s & -Leprosy vaccine marketed by Cadila Pharma, India \\
\hline & & Satish Gupta/NII/1982 & -Made first Hybridome \\
\hline & & B. Saha/NCCS/ 1997 & -Immuno-therapy for Leishmania \\
\hline 3. & Diagnostics & Chauahan NK/ AIIMS/ 2005 & -Rk-39 ICT test for detection of Kala Azar \\
\hline
\end{tabular}

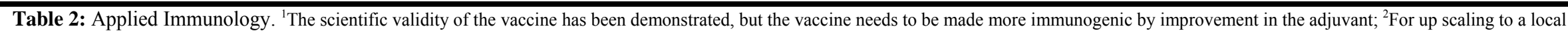
industry; ${ }^{3}$ Ready for Phase I clinical trials; ${ }^{4}$ under Clinical trials

ISSN 0973-2063

Bioinformation 2(1): 34-38 (2007) 


\section{Bioinformation}

\section{www.bioinformation.net}

\section{Views \& Challenges}

\section{[Interesting publications in the field of Immunology from India]}

1) Lysophospholipid sensing triggers secretion of flagellin from pathogenic Salmonella. Nat. Immunol. 7(6):583 (2006). [QADRI]

2) MHC class I-restricted presentation of maleylated protein binding to scavenger receptors. J Immunol. 162(8):4430 (1999). [RATH]

3) A vaccine that prevents pregnancy in women. Proc Natl Acad Sci U S A. 91(18):8532. (1994) [TALWAR]

4) Differential epitope positioning within the germline antibody paratope enhances promiscuity in the primary immune response. Immunity. 4:429 (2006). [SALUNKE]

5) Differential CD40/CD40L expression results in counteracting anti-tumor immune responses. $J$ Immunol. 178(4):2047 (2007) [SAHA]

6) A GPI-linked isoform of the $\operatorname{IgD}$ receptor regulates resting B cell activation. Nat Immunol. 10:951 (2002) [KANURY RAO]

7) Resveratrol and curcumin suppress immune response through CD28/CTLA-4 and CD80 co-stimulatory pathway. Clin Exp Immunol. 147(1):155 (2007). [AGREWALA]
8) Role of NF-kappaB signaling pathway in increased tumor necrosis factor-alpha-induced apoptosis of lymphocytes in aged humans. Cell Death Differ. 12(2):177 (2005). [CHIPLUNKAR]

9) Impaired generation of reactive oxygen species during differentiation of dendritic cells (DCs) by Mycobacterium tuberculosis secretory antigen (MTSA) and subsequent activation of MTSA-DCs by mycobacteria results in increased intracellular survival. J Immunol. 177(1):468 (2006) [NATARAJAN]

10) Anti-idiotype-mediated epitope spreading and diminished phagocytosis by a human monoclonal antibody recognizing late-stage apoptotic cells. Cell Death Differ. 13(10):1715 (2006) [RAHUL PAL]

11) Immune responses to asexual blood-stages of malaria parasites. Curr Mol Med. 6(2):187 (2006). Review. [CHITNIS]

12) Transporter associated with antigen-processing (TAP) genes and susceptibility to tuberculoid leprosy and pulmonary tuberculosis. Tissue Antigens. 49(2):168 (1997) [MEHRA]

13) Execution of macrophage apoptosis by PE_PGRS33 of Mycobacterium tuberculosis is mediated by Toll-like receptor 2-dependent release of tumor necrosis factoralpha. J Biol Chem. 282(2):1039 (2007). [BASU] 